
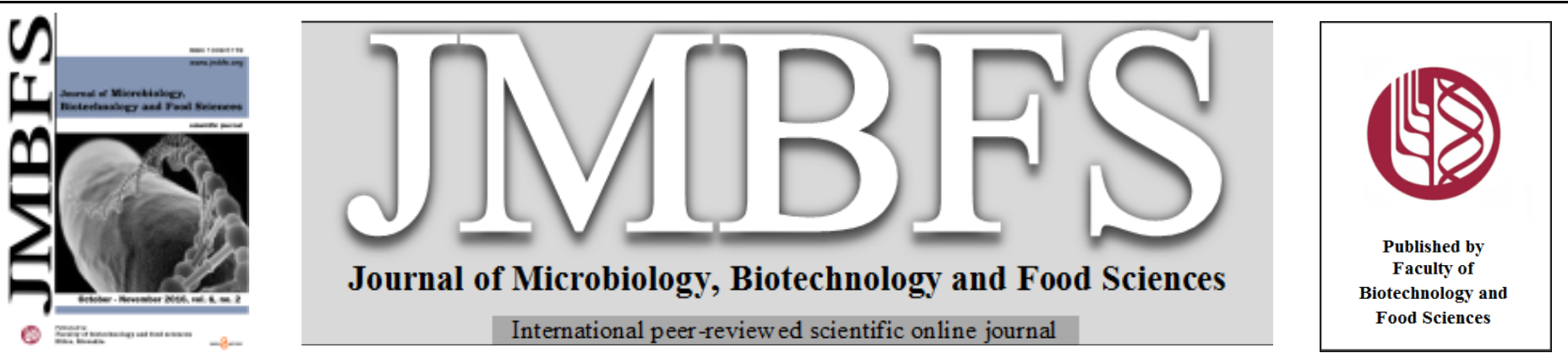

\title{
PHENOLIC COMPOUDNS IN TRADITIONAL BULGARIAN MEDICAL PLANTS
}

\section{Lyubomir M. Atanassov ${ }^{1}$, Mohammad Ali Shariati ${ }^{2}$, Maria S. Atanassova ${ }^{3}$, Muhammad Usman Khan $^{4}$, Majid Majeed $^{5}$, Shilan Rashidzadeh ${ }^{6}$}

\author{
$\operatorname{Address}(e s):$ \\ ${ }^{1}$ Sudent, MIPT, Russia. \\ ${ }^{2}$ Research Department, LLC «Science \& Education», Russia and Researcher All Russian Research Institute of Phytopathology, Moscow Region, Russia. \\ ${ }^{3}$ Independent Researcher Sofia, Bulgaria. \\ ${ }^{4}$ Department of Energy Systems Engineering, University of Agriculture Faisalabad,38000,Faisalabd,Pakistan,+92312667362 \\ ${ }^{5}$ National institute of Food Science and Technology, University of Agriculture, Faisalabad,38000,Faisalabd,Pakistan,+92312667362. \\ ${ }^{6}$ Department of Food Science and Technology, Gorgan Payame Nour University, Gorgan, Iran.
}

*Corresponding author: stefanova@myway.com

doi: 10.15414/jmbfs.2016.6.2.858-862

ARTICLE INFO

Received 6. 7. 2016

Revised 17. 8. 2016

Accepted 14. 9. 2016

Published 3. 10. 2016

Regular article

open $\odot$ access

\begin{abstract}
A number of plants and plant products have medicinal properties that have been validated by recent scientific developments throughout the world, owing to their potent pharmacological activity, low toxicity and economic viability. In recent years, the use of natural antioxidants present in traditional medicinal plants has become of special interest in the scientific world due to their presumed safety and nutritional and therapeutic value. In this present study, comparative phenolic compounds in traditional Bulgarian medical plants. The medical plants were analyzed for their tannins content by titrimetric method; rutin was determined spectrophotometrically by using ammonium molybdate; the total phenolics content was determined by using Folin-Ciocalteu assay and the total flavonoids were used the colorimetric reaction with aluminum (III) chloride. The present paper shown by the results of total phenolic and total flavonoid contents, and rutin and tannins in medical plants that they must be relatively safe for the patient.
\end{abstract}

Keywords: chicory(Cichoriumintybus L.), white birch (Betula pendula),Cotinuscoggygria, Geranium sanguineumL. and rose hip fruits (Rosa caninaL.), total phenolics, total flavonoids, rutin and tannins

\section{INTRODUCTION}

The World Health Organization (WHO) has estimated that almost $80 \%$ of the earth's inhabitants believe in traditional medicine for their primary health care needs, and that most of this therapy involves the use of plant extracts and their active components (Kishore Dubey et al., 2015; Winston, 1999). A number of plants and plant products have medicinal properties that have been validated by recent scientific developments throughout the world, owing to their potent pharmacological activity, low toxicity and economic viability (Kishore Dubey $\boldsymbol{e}$ al., 2015) .In recent years, the use of natural antioxidants present in traditional medicinal plants has become of special interest in the scientific world due to their presumed safety and nutritional and therapeutic value (Kishore Dubey et al., 2015; Ajila et al., 2007). The majority of the antioxidant activity of plants is due to the presence of phenolic compounds (flavonoids, phenolic acids and alcohols, stilbenes, tocopherols, tocotrienols), ascorbic acid and carotenoids (Kishore Dubey et al., 2015)

Bulgaria is situated in the Balkan Peninsula, South-East Europe, Mediterranean and continental climates. The relief of the country is quite diverse ranging from plains to low hills and high mountains. The climate is moderate continental to modified continental, but in southern regions reflects rather a strong Mediterranean influence. As a result of this climatic condition, the Bulgarian flora is remarkable for its diversity (3500 plant species including 600 known medicinal plants) (Ivancheva and Stancheva, 2000 ;Ivancheva et al., 2006).

Traditional Bulgarian medicinal plants have been used to treat human diseases in Bulgaria for thousands of years, and people are becoming increasingly interested in them because of their good health effects and low toxicity. In recent years, studies on the antioxidant activities of Traditional Bulgarian medicinal plants have increased remarkably in light of the increased interest in their potential as a rich source of natural antioxidants. Several studies have indicated that Traditional Bulgarian medicinal plants possess more potent antioxidant activities than common dietary plants, and contain a wide variety of natural antioxidants, such as total phenolics, flavonoidsand tannins (Atanassova et al., 2011).

In recent years, interest in plant-derived food additives has grown. Furthermore plant extracts of Bulgarian white birch (Betula pendulaL.) leaves have been shown to possess health-promoting properties. The white birch leaves extract were strong diuretic and have effect at nephrolithiasis and urinary bladder lythiasos, sedative effect on spasms of smooth muscle. It might be used in following conditions: kidney diseases, ischia nerve inflammation and podagra and atherosclerosis and also it has an antimicrobial effect (ChristovaBagdassrian et al., 2014; Harbone, 1993).

The extracts from the leaves of the white birch significantly increase diuresis, and with this and the emission of sodium and chloride ions, ie act as salidiuretik. Until recently it was assumed that the diuretic action is due to the presence of resinous substances. Therefore birch buds were preferred because they are rich in resins. However, it is clear that flavonoids have a greater role in the diuretic effect. They are contained mainly in the leaves. In addition, the leaves contain potassium nitrate, which enhances the diuretic effect of the flavonoids. This effect was related to total flavonoids (Christova-Bagdassrian et al., 2014; Neoretal , 2006).

Cotinus coggygriais one of two species constituting a minor genus of the family Anacardiaceae, viz., Cotinus coggygriaScop. (syn.: Rhus cotinus L.) Itself and Cotinusobovatus Raf., the American smoketree. Its wide distribution extends from southern Europe, the Mediterranean, Moldova and the Cauca-sus, to central China and the Himalayas (Christova-Bagdassarian et al., 2016; Novakovic et al., 2007; Matic et al., 2011). C. coggygriais a common medicinal plant (well known as 'smradlika' or 'tetra') in the Bulgarian folk medicine for outer use predominantly (Christova-Bagdassarian et al., 2016; Landzhev Chemical, I., 2010; Ivanova et al., 2013).

Plants of the family Anacardiaceae have a long history of use by various peoples for medicinal and other purposes. Rhus glabrais traditionally used in the treatment of bacterial diseases such as syphilis, gonorrhea, dysentery and gangrene, while $R$. coriaria, besides its common use as a spice consisting of ground dried fruits with salt, is also widely used as a medicinal herb, particularly for wound healing (Christova-Bagdassarian et al., 2016; Matic et al., 2011; Rayne and Mazza, 2007)

In folk medicine, Cotinus coggygriais routinely used as an antiseptic, antiinflamatory, antimicrobial and antihaemorragic agent in wound-healing (Christova-Bagdassarian et al., 2016; Rayne and Mazza, 2007; Demirci et al., 
2003), as well as for countering diarrhea, paradontosis, and gastric and duodenal ulcers (Christova-Bagdassarian et al., 2016; Rayne and Mazza, 2007; Ivanova et al., 2007). However, these by-products are still a good and cheap source of high-quality polyphenolic compounds which can be used in different therapeutic procedures with the purpose of free radical neutralisation in biological systems (Christova-Bagdassarian et al., 2016; Bucić-Kojić et al., 2007; Heim et al., 2002; Yilmaz and Toledo, 2004)

Cichorium intybus L., commonly known as chicory, belongs to family Asteraceae and widely distributed in Asia and Europe(ZahidKhorshid et al., 2015; Bais $\boldsymbol{e}$ al., 2001). All parts of this plant possess great medicinal importance due to the presence of a number of medicinally important compounds such as alkaloids, inulin, sesquiterpene lactones, coumarins, vitamins, chlorophyll pigments, unsaturated sterols, flavonoids, saponins and tannins (ZahidKhorshid $\boldsymbol{e t}$ al., 2015; Bais et al., 2001, Atta et al., 2010; Molan et al., 2003; Muthusamy et al., 2008; Nandagopal et al., 2007). The whole plant has numerous applications in food industry and medicine (Denev et al., 2014; Ilaiyaraja et al., 2010). Its dried roots were used as a substitute or adulterant in coffee powder (Denev et al., 2014; Jung et al., 1994). The young leaves can be added tosalads and vegetable dishes, while chicory extracts are used for the production of invigorating beverages (Denev et al., 2014).Leaves of chicory are good sources of phenols, vitamins $\mathrm{A}$ and $\mathrm{C}$ as well as potassium, calcium, and phosphorus (ZahidKhorshid et al., 2015; Muthusamy et al.,2008) $C$. intybus has been traditionally used for the treatment off ever, diarrhea, jaundice and gallstones (ZahidKhorshid et al., 2015; Abbasi et al., 2009; Afzal et al., 2009).During the past decade, there is a growing interest in natural plant extracts with potential antioxidant activity, because of their improved healthy effect (Denev et al., 2014; Alexieva et al., 2013; Mihaylova et al., 2013). The expanded application is due to their protective properties against oxidative stress disorders, as well asoxidative damage in food products (Denev et al., 2014; Ivanov et al., 2014).I is well known that polyphenols from plant extracts possessed strong antioxidan activities. Their presence in medicinal plant that are natural source of inulin-type fructans prebiotics additionally increase the biological activity of the obtained extracts (Denev et al., 2014; Petkova et al., 2012; Vrancheva et al., 2012)

Wild growing rose hip fruits (Rosa canina L.) are widespread plant in Bulgaria with great importance in herbal medicine. The Rosa canina fruits are a valuable source for food and pharmaceutical industry. They contain a wide variety of biologically and physiologically active ingredients, such as vitamins $(\mathrm{C}, \mathrm{B}, \mathrm{P}, \mathrm{PP}$, E, K), flavonoids, carotenes, carbohydrates (mono- and oligosaccharides), organic acids (tartaric, citric), trace elements and others (Taneva et al., 2016; Ognyanov et al., 2014; Mihaylova et al., 2015).

These compounds play an important role in maintaining fruit quality and determining nutritive value. Rose hips are also well known to have the highest vitamin C content (300-4000 mg/100 g) among fruits and vegetables (Taneva $\boldsymbol{e}$ al., 2016; Demir et al., 2001). In Bulgaria rose hip fruits are typically consumed as infusion. It was found that juice and aqueous extracts from rose hip possessed exceptional antioxidant activity (Taneva $e t$ al., 2016; Demir et al., 2001). This makes them suitable for use both in the fresh or dry state, or in the form of extracts in food products and cosmetics (Taneva et al., 2016; Ognyanov et al. 2014; Mihaylova et al., 2015). According to some authors, the higher values of antioxidant activity of rose hip extracts due to synergism between polysaccharides and organic acids (gallic, cinnamic, ellagic), with phenolic antioxidants: flavonoids (rutin, kaempferol, quercetin) (Taneva et al., 2016; Ognyanov et al., 2014; Mihaylova et al., 2015).

The most common antioxidants contained in fruits are ascorbic acid, carotenoids and polyphenol substances with proven antioxidant capacity (Taneva $\boldsymbol{e t} \boldsymbol{a l}$. 2016; Mihaylova et al., 2015).

Geranium macrorrhizum L.is a perennial herb native from the Balkans, occurring occasionally also in the Carpathian Mountains and in the Alps. It is known as "Zdravets" which means "healthy" in Bulgarian folk medicine. A methanol extract from leaves possesses strong hypotensive activity, cardiotonic, capillary anticomplementary and sedative action as well (Ivancheva $\boldsymbol{e t}$ al., 2006; Genova et al., 1989; Ivancheva and Wollenweber, 1989; Ivancheva et al., 1992). Central depressive action of methanol extracts has also been demonstrated. The whole plant is rich in tannins with more in the stems than in the green foliage. No alkaloids and cardiological glycosides have been found The presence of six flavonol aglycones in aerial parts of G. macrorrhizum has been established (kaempferol 3-methylether (isokaempferide), kae-3,7dimethylether (kumataketin), kae-3,4'- dimethylether (ermanin), quercetin, qu7,3'-dimethylether and qu-3,7,3',4'-tetramethylether (retusin)); two of these, namely ermanin and retusin were said to be present in the roots too (Ivancheva $e$ al., 2006). The focus in the present study is a comparative evaluation of the total phenolic and total flavonoid contents, rutin and tannins in traditional Bulgarian medical plants as sources for human health.

\section{MATERIAL AND METHODS}

\section{Plant material}

The leaves from chicory (Cichorium intybus L.), white birch (Betula pendula), zdravec (Geranium macrorrhizum L.), smradlika (Cotinus coggygria, syn.: Rhus cotinus L.) and rose hip fruits (Rosa canina L.) were harvested from different regions of Bulgaria. All sample data are stated in the sampling protocol. The dried leaves and rose hip fruit were kept in a dry place until further use.

\section{Sample preparation}

A dry simple of $0.5 \mathrm{~g}$ was weighted and phenolic and flavonoid compounds were extracted with $50 \mathrm{~mL} 80 \%$ aqueous methanol on an ultrasonic bath for $20 \mathrm{~min}$. An aliquot $(2 \mathrm{~mL})$ of the extracts was ultracentrifugated for $5 \mathrm{~min}$ at $14000 \mathrm{rpm}$. The extract prepared in this way was used for further spectrophotometric determination of polyphenols.

\section{Determination of total phenolics assay}

The total phenolic contents of medicinal plants were determined by using the Folin-Ciocalteu assay.An aliquot $(1 \mathrm{~mL})$ of extracts or standard solution of gallic acid $(10,20,40,60,80,100$ and $120 \mathrm{mg} / \mathrm{L})$ was added to $25 \mathrm{~mL}$ volumetric flask, containing $9 \mathrm{~mL}$ of distilled deionised water $\left(\mathrm{dd}_{2} \mathrm{O}\right)$. A reagent blank using dd $\mathrm{H}_{2} \mathrm{O}$ was prepared. One milliliter of Folin-Ciocalteu's phenol reagent was added to the mixture and shaken. After $5 \mathrm{~min}, 10 \mathrm{~mL}$ of $7 \% \mathrm{Na}_{2} \mathrm{CO}_{3}$ solution was added to the mixture. To the solution the $\mathrm{dd}_{\mathrm{H}} \mathrm{O}$ was added up to volume of $25 \mathrm{~mL}$ and mixed. After incubation for $90 \mathrm{~min}$ at room temperature, the absorbance against prepared reagent blank was determined at $750 \mathrm{~nm}$ with an UV-Vis Spectrophotometer BOECO - Germany. All samples were analyzed in duplicates (Marinova et al., 2005).

\section{Determination of total flavonoids assay}

The total flavonoid contents were measured by aluminum chloride colorimetric assay. An aliquot $(1 \mathrm{~mL})$ of extracts or standard solution of catechin $(10,20,40$ $60,80,100$ and $120 \mathrm{mg} / \mathrm{L}$ ) wasadded to $10 \mathrm{~mL}$ volumetric flask, containing $4 \mathrm{~mL}$ of distilled deionised water $\left(\mathrm{dd}_{2} \mathrm{O}\right)$. To the flask was added $0.3 \mathrm{~mL} 5 \% \mathrm{NaNO}_{2}$ After $5 \mathrm{~min}, 0.3 \mathrm{~mL}$ of $10 \% \mathrm{AlCl}_{3}$ was added. At $6^{\text {th }} \mathrm{min}, 2 \mathrm{~mL} 1 \mathrm{M} \mathrm{NaOH}$ was added and the total volume was made up to $10 \mathrm{~mL}$ with dd $\mathrm{H}_{2} \mathrm{O}$. The solution was mixed well and the absorbance was measured against prepared reagent blank at 510nm. UV-Vis Spectrophotometer BOECO - Germany. All samples were analyzed in duplicates (Marinova et al., 2005).

\section{Rutin assay}

The analyses of rutin content in Bulgarian medicinal plants were performed according to The International Pharmacopoeia and AOAC method, after modified methods with using $80 \%$ aqueous methanol. Pipet $2 \mathrm{~mL}$ aliquots solution into 50 $\mathrm{mL}$ volumetric flask was added to $2 \mathrm{~mL}$ deionized water (dd $\mathrm{H} 2 \mathrm{O}$ ) and $5 \mathrm{~mL}$ ammoniummolybdat. The solution was added volume $(50 \mathrm{~mL})$ with dd $\mathrm{H} 2 \mathrm{O}$ and mixed. Was prepared standard solution of rutin $(0.0200 \mathrm{~g}$ dissolved into $2 \mathrm{~mL}$ methanol) was added volume $(50 \mathrm{~mL})$ with $80 \%$ aqueous methanol. An aliquot (1 $\mathrm{mL}$ ) of standard solution into $50 \mathrm{~mL}$ volumetric flask and dilute to volume with distilled deionized water $\left(\mathrm{dd}_{2} \mathrm{O}\right)$. A reagent blank using dd $\mathrm{H}_{2} \mathrm{O}$ was prepared The absorbance against prepared reagent blank was determined at $360 \mathrm{~nm}$ with an UV-Vis Spectrophotometer BOECO - Germany. All samples were analyzed in duplicates (Atanassova et al., 2009a).

\section{Calculations}

Calculations are based on averaging results from analyses of duplicate samples. Calculate content $(\%)$ of rutin $(\mathrm{R})$ in sample as follows:

$$
\mathrm{R}(\%)=\frac{A_{\text {sample }} \times C \times 50 \times 100}{A_{\text {stand }} \times W \times 2}
$$

Where:

$A_{\text {sample }}$ - Absorbance of sample was determined at $360 \mathrm{~nm}$;

$A_{\text {stand }^{-}}$Absorbance of standard solution was determined at $360 \mathrm{~nm}$;

$\mathrm{C}-$ Concentration of standard solution of rutin $(\mathrm{g} / \mathrm{mL})$;

$\mathrm{W}$ - weight ( $\mathrm{g}$ ) of sample for analyses;

2 - Volume $(\mathrm{mL})$ of sample for analyses;

100 - Percent, $\%$.

\section{Tannins assay}

The analyses of tannins content in traditional Bulgarian medicinal plantswere performed according to The International Pharmacopoeia and AOAC method, after modified methods. Measured $25 \mathrm{~mL}$ of this infusion into $1 \mathrm{~L}$ conical flask and add $25 \mathrm{~mL}$ indigo solution and $750 \mathrm{~mL}$ distilled deionized water $\left(\mathrm{dd} \mathrm{H}_{2} \mathrm{O}\right)$. Titred with $0.1 \mathrm{~N}$ water solution of $\mathrm{KMnO}_{4}$ until blue solution changes to green, then add a few drops at time until solution becomes golden yellow. Was prepared standard solution of Indigo carmine (dissolve $6 \mathrm{~g}$ indigo carmine in $500 \mathrm{~mL}$ distilled deionized water ( $\mathrm{dd}_{2} \mathrm{O}$ ) by heating, cool add $50 \mathrm{~mL} 96 \%-98 \%$ $\mathrm{H}_{2} \mathrm{SO}_{4}$, diluted to $1 \mathrm{~L}$ and then filtered. For the blank similarly titred mixture of 
$25 \mathrm{~mL}$ indigocarmine solution and $750 \mathrm{~mL} \mathrm{ddH}_{2} \mathrm{O}$. All samples were analyzed in duplicates (Atanassova et al., 2009b).

\section{Calculations}

Calculations are based on averaging results from analyses of duplicate samples. Calculate content (\%) of tannins (T) in sample as follows:

$$
\mathrm{T}(\%)=\frac{\left(V-V_{0}\right) \times 0.004157 \times 250 \times 100}{g \times 25}
$$

Where:

$\mathrm{V}$ - Volume of $0.1 \mathrm{~N}$ water solution of $\mathrm{KMnO}_{4}$ for titration of sample, $\mathrm{mL}$;

$\mathrm{V}_{0}$ - Volume of $0.1 \mathrm{~N}$ water solution of $\mathrm{KMnO}_{4}$ for titration of blank sample, $\mathrm{mL}$;

0.004157 - Tannins equivalent in $1 \mathrm{~mL}$ of $0.1 \mathrm{~N}$ water solution of $\mathrm{KMnO}_{4}$;

$\mathrm{g}$ - Mass of the sample for analyses, $\mathrm{g}$;

250 - Volume of volumetricflask, $\mathrm{mL}$;

100 - Percent, \%.

\section{Statistical analysis}

All experiments were performed in triplicates. Analysis at every time point from each experiment was carried out induplicate or triplicate. The statistica parameters are calculated in terms of the reproducibility of the experimental data using a statistical package universal ANOVA.

\section{RESULTS AND DISCUSSION}

Different phytochemicals have various protective and therapeutic effects which are essential to prevent diseases and maintain a state of well being. Methanolic extract of rose hip fruits (Rosa canina L.), chicory (Cichorium intybus L.), zdravec (Geranium macrorrhizum L.), smradlika (Cotinus coggygria, syn.: Rhus cotinus L.) and white birch (Betula pendula L.) were analyzed for phytoconstituents. The quantitative estimation of phenolic compounds of white birch (Betula pendula L.), smradlika (Cotinus coggygria, syn.: Rhus cotinus L.) zdravec (Geranium macrorrhizum L.), chicory (Cichorium intybus L.) and rose hip fruits (Rosa canina L.) show that the traditional Bulgarian medical plants are rich in total phenolics, total flavonoids according to the data shown in the Table1 and Figure 1. It is well that plant flavonoids and phenols in general, are highly effective free radical scavenging and antioxidants. The phenolic constituents found in herbs have attracted considerable attention as being the main agents of antioxidant activity, although they are not the only ones. The antioxidant activity of phenolic compounds is mainly due to their redox properties, which allow them to act as reducing agents, hydrogen donors and singlet oxygenquenchers. In addition, they have a metal chelation potential. Hence, the antioxidantactivity of phenolics plays an important role in the adsorption or neutralization of free radicals (Dutra et al., 2008; Laguerre et al., 2007).

The major compounds that are related to the antioxidant potential of a plant (or plant part) are the total phenolics and, more specifically, the flavonoids (Dutra $\boldsymbol{e}$ al., 2008; Kumar Ashok et al., 2012), though there is no consensus as to whether these are the sole substances in plants that act in scavenging free radicals. It is well known that plant phenolics, in general are highly effective in free radical scavenging and they are antioxidants. The presence of these phytochemicals in medical plants is thus a significant finding of the present study. The content of total phenolics and total flavonoids in white birch (Betula pendula $\mathrm{L}$.), varying between $5256,30 \mathrm{mg} \mathrm{GAE} / 100 \mathrm{~g}$ dw to $2245,70 \mathrm{mg} \mathrm{CE} / 100 \mathrm{~g}$ $\mathrm{dw}$, was found to be much higher than and in rose hip fruits (Rosa canina L.) $406,79 \mathrm{mg}$ GAE/100g dw to $290,13 \mathrm{mg} \mathrm{CE} / 100 \mathrm{~g}$ dw, respectively, as shown in Table 1 and Figure 1 with gallic acid and catechin as standards. These results indicate that the higher antioxidant activity of the white birch (Betula pendula L.) methanol extract, compared to the rose hip fruits (Rosa canina L.) methano extract, may be correlated to the phenolic and flavonoid content of respective medical plant extract.

Table 1 Total phenolics and total flavonoids in studied Traditional Bulgarian medical plants

\begin{tabular}{lcc}
\hline Bulgarian medical plants & $\begin{array}{c}\text { Total phenolics, } \\
\text { (mg GAE/100g dw) }\end{array}$ & $\begin{array}{c}\text { Total flavonoids, } \\
\text { (mg CE/100g dw) }\end{array}$ \\
\hline Rose hip fruits (Rosa canina & $406,79 \div 0,02$ & $290,13 \div 0,01$ \\
L.) & (RDS 0,$03 ; \mathrm{n}=3)$ & (RDS 0,$03 ; \mathrm{n}=3$ ) \\
Chicory (Cichorium intybus & $635,87 \div 0,05$ & $315,15 \div 0,04$ \\
L.) & (RDS 0,$07 ; \mathrm{n}=3)$ & (RDS 0,$01 ; \mathrm{n}=3$ ) \\
Zdravec (Geranium & $1530,70 \div 0,02$ & $110,20 \div 0,06$ \\
macrorrhizum L.) & (RDS 0,$01 ; \mathrm{n}=3)$ & (RDS 0,$05 ; \mathrm{n}=3)$ \\
Smradlika (Cotinus & $2581,60 \div 0,02$ & $810,40 \div 0,04$ \\
coggygria, syn.: Rhus & (RDS 0,$08 ; \mathrm{n}=3)$ & (RDS 0,$04 ; \mathrm{n}=3$ ) \\
cotinus L.) & $5256,30 \div 0,04$ & $2245,70 \div 0,04$ \\
White birch (Betula pendula & (RDS 0,$08 ; \mathrm{n}=3)$ & (RDS 0,$01 ; \mathrm{n}=3$ ) \\
L.) & &
\end{tabular}

\section{Total phenolics and total flavonoids in Traditional Bulgarian medical plants}

- Total phenolics, $(\mathrm{mg} \mathrm{GAE} / 100 \mathrm{~g} \mathrm{dw}) \quad \square$ Total flavonoids, (mg CE/100g dw)

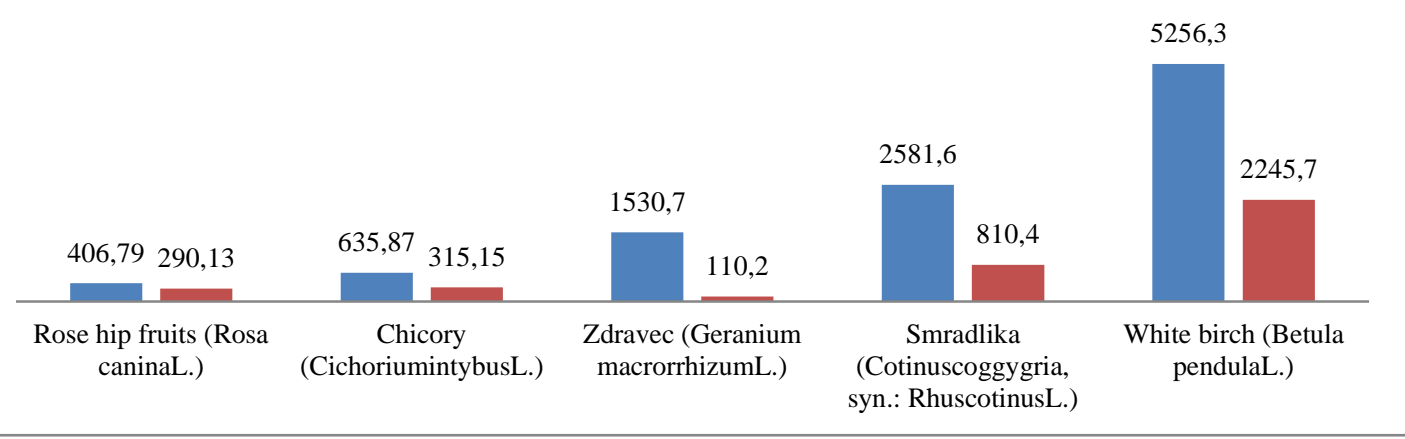

Figure 1 Total phenolics and total flavonoids in Traditional Bulgarian medical plants

The presence of rutin and tannins in chicory (Cichorium intybus L.), rose hip fruits (Rosa canina L.), zdravec (Geranium macrorrhizum L.), white birch (Betula pendula L.) and smradlika (Cotinus coggygria, syn.: Rhus cotinus L.) show that the traditional Bulgarian medical herbs are rich in tannins, rutin according to the data shown in the Table 2 and Figure 2. The phytochemical screening and quantitative estimation of the percentage of chemical constituents of the plants studied showed that the dry herbs were rich in rutin and tannins. Tannins are distributed all over the plant kingdom (Bate-Smith, 1962). The term tannin refers to the use of tannins in tanning animal hides into leather; however, the term is widely applied to any large polyphenolic compound containing sufficient hydroxyls and other suitable groups (such as carboxyls) to form strong complexes with proteins and other macromolecules. Tannins have molecular weights ranging from 500 to over 3000 (Bate-Smith, 1962; Cheng et al., 2003) Tannins may be employed medicinally in antidiarrheal, haemostatic, and antihemorrhoidal compounds (Bate-Smith, 1962; Lin et al., 2004). Tannins can also be effective in protecting the kidneys $(52,55)$. Tannins are also beneficial when applied to the mucosal lining of the mouth (Bate-Smith, 1962; Habtemariam and Varghese, 2015). Rutin is a common dietary flavonoid widely distributed in the plant kingdom. It is also present in plant-derived beverages and foods as well as numerous medicinal and nutritional preparations (Sando and Lloyd, 1924; Habtemariam and Varghese, 2015). Today, rutin is among the most popular natural flavonoids known for its multifunctional nutritional and therapeutic uses (Sando and Lloyd, 1924; Habtemariam and Lenti, 2015). As far as commercial exploitation of rutin is concerned, however, very few plants store it in large amounts to merit the cost of its extraction from natural sources (Sando and Lloyd, 1924). They were known to show medicinal activity as well as exhibiting physiological activity. The presence of these phenolic compounds in traditional Bulgarian medical herbs is a significant finding in this present study. The content for rutin of white birch (Betula pendula L.) varied between $6,24 \%$ was found to be much higher than and chicory (Cichorium intybus L.) - 2,09\%, respectively as shown in Table 2 and Figure 2 with rutin as

standards. The content for tannins of smradlika (Cotinus coggygria, syn.: Rhus cotinus L.) varied between $11,15 \%$ was found to be much higher than and chicory (Cichorium intybus L.) - 2,26\%, respectively as shown in Table 2 and Figure 2 and $\mathrm{KMnO} 4$ as titrate. It is important to notice that the comparison of 
the results for rutin and tannin contents in the medical herbs will be not correct because of the different methods of analysis.

Table 2 Tannins and rutin in studied Traditional Bulgarian medical plants

\begin{tabular}{lcc}
\hline Bulgarian medical plants & Tannins, (\%) & Rutin, (\%) \\
\hline Chicory (Cichorium intybus & $2,26 \div 0,04$ & $2,09 \pm 0,01$ \\
L.) & (RDS 1,$8 ; \mathrm{n}=3)$ & (RDS 0,$6 ; \mathrm{n}=3$ ) \\
Rose hip fruits (Rosa canina & $4,11 \pm 0,09$ & $2,16 \pm 0,04$ \\
L.) & (RDS 2,$3 ; \mathrm{n}=3)$ & (RDS 1,$9 ; \mathrm{n}=3$ ) \\
Zdravec (Geranium & $6,08 \pm 0,07$ & $3,20 \pm 0,08$ \\
macrorrhizum L.) & (RDS 1,$2 ; \mathrm{n}=3)$ & (RDS 2,$3 ; \mathrm{n}=3)$ \\
White birch (Betula pendula & $9,04 \pm 0,03$ & $6,24 \pm 0,02$ \\
L.) & (RDS 0,$4 ; \mathrm{n}=3)$ & (RDS 0,$3 ; \mathrm{n}=3)$ \\
Smradlika (Cotinus coggygria, & $11,15 \pm 0,06$ & $3,06 \pm 0,06$ \\
syn.: Rhus cotinus L.) & (RDS 0,$5 ; \mathrm{n}=3$ ) & (RDS 1,$9 ; \mathrm{n}=3$ ) \\
\hline
\end{tabular}

\section{CONCLUSION}

In conclusion, on the basis of the results of this research showed that total phenolic, total flavonoid, rutin and tannin contents are important components in traditional Bulgarian medical plants grown in the country. The use of medical plants as the first choice in self0treatment of minor conditions continues to expand rapidly across the world. This makes the safety of medical plants an important public health issue. The results can be used in public health campaigns to stimulate the consumption of traditional Bulgarian plants as chicory (Cichorium intybus L.), rose hip fruits (Rosa canina L.), zdravec (Geranium macrorrhizum L.), white birch (Betula pendula L.) and smradlika (Cotinus coggygria, syn.: Rhus cotinus L.) which are able to provide significant health protection in order to prevent chronic diseases.

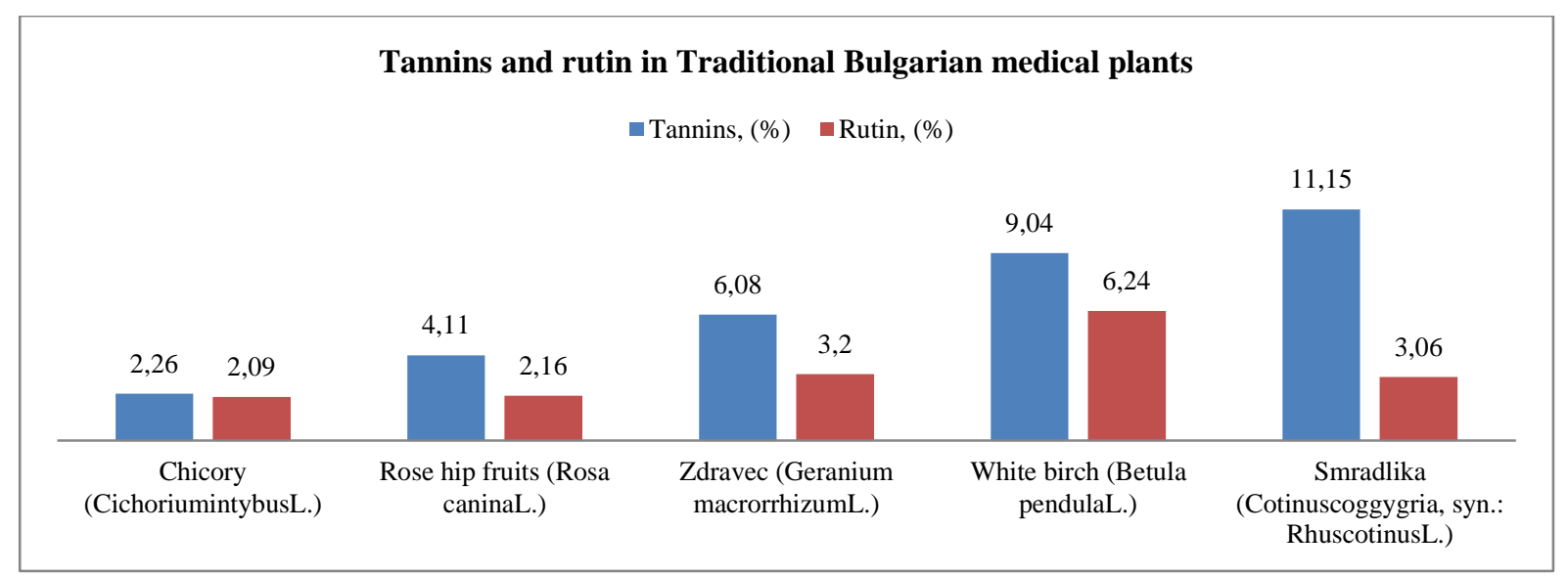

Figure 2 Tannins and rutin in Traditional Bulgarian medical plants

\section{REFERENCES}

Abbasi, A.M., Khan, M.A., Ahmad, M., Zafar, M., Khan, H.,Muhammad, N., Sultana, S., 2009. Medicinalplants used for thetreatment of jaundice and hepatitisbasedonsocio-economicdocumentation. African Journal of Biotechnology, 8(8), 1643-1650.

Afzal, S., Afzal, N., Awan, M.R., Khan, T.S., Gilani, A., Khanum, R., \&Tariq, S. (2009). Ethno-botanicalstudies from NorthernPakistan .Journal of Ayub Medical College Abbottabad, 21(1), 52-57.

Ajila, C.M., Naidu, K.A., Bhat, U.J.S, \& Rao, P. (2007) Bioactive compounds and antioxidant potential of mango peel extract. Food Chemistry,105, 982-988. http://dx.doi.org/10.1016/j.foodchem.2007.04.052

Alexieva, I., Mihaylova, D., \& Popova, A. (2013). Evaluation of theantioxidantcapacity of aqueous extracts of freshsamardala (AlliumbulgaricumL.) leaves. Scientific works, 826-831.

Atanassova, M., \& Christova-Bagdassarian, V. (2009). Determination of tanninscontent by titrimetricmethod for comparison of different plantspecies. Journal of the University of Chemical TechnologyandMetallurgy, 44(44), 413415.

Atanassova M., \& Bagdassarian ,V. (2009). Rutin content in plantproducts. Journal of the University of Chemical Technology and M Marinova, D. Ribarovam F., Atanassova, M.(2005). Total phenolics and total flavonoids in Bulgarian fruits and vegetables. Journal of the University of Chemical Technology and Metallurgy, 40(3), 255-260.

Atanassova, M., Georgieva, S., \& Ivancheva, K. (2011). Total phenolic and total flavonoid contents, antioxidant capacity and biological contaminants in medicinal herbs. Journal of the University of Chemical Technology and Metallurgy, 46(1), $81-88$.

Atta, A.H., Elkoly T.A., Mouneir, S.M., Kamel G., Alwabel, N.A., \&Zaher, S (2010). Hepatoprotective effect of methanol extracts of Zingiber officinale and Cichorium intybus . Indian Journal of pharmacy science, 72(5), 564-570. http://dx.doi.org/10.4103/0250-474x.78521

Bate-Smith, S. (1962). Flavonoid compounds. In: Comparative biochemistry. Florkin M Mason HS (Eds), Vol III, Academic Press, New-York, 75-809. http://dx.doi.org/10.1016/b978-0-12-395544-9.50025-x

Bais, H.P., Ravishankar, G.A., \&Cichoriumintybus, L. (2001) cultivation,processing, utility, valueaddition and biotechnology, with anemphasison current status and futureprospects. Ournal of the science of food and agriculture. 81,467-484. http://dx.doi.org/10.1002/jsfa.817.abs

Bucić-Kojić, A., Planinić, M., Tomas, S., Bilić, M., \& Velić, D. (2007). Study of solid-liquid extraction kinetics of total polyphenols from grape seeds. Journal of
Food

Engineering,

81

$236-242$

http://dx.doi.org/10.1016/j.jfoodeng.2006.10.027

Cheng, H.Y., Lin, C.C., \& Lin, T.C. (2002). Antiherpes simplex virus type 2 activity of casuarinin from the bark of Terminalia arjuna Linn. Antiviral Researc 55, 447-455. http://dx.doi.org/10.1016/s0166-3542(02)00077-3

Christova-Bagdassrian, V.L., Chohadjieva, D., \& Atanassova, M. (2014). Total Phenolics and Total Flavonoids, Nitrate Contents and Microbiological Tests in Dry Extract of Bulgarian White Birch Leaves (Betula pendula). International Journal of Advanced Research, 2 (6), 668-674

Christova-Bagdassarian, V.L., Atanassova, M.S., Hristova, V.K., \& Ahmad, M.A. (2016). Soild-Liquid Extraction Kinetics of Total Phenolic, Total Flavonoid, Rutin and Tannin Contents in 50\% Ethanol Extract of Cotinuscoggygria. International Journal of Scientific \& Engineering Research, $7(2)$.

Demir 9F., \& Ozcan, M. (2001). Chemical and technological propertiesof rose (Rosa caninaL.) fruits grown wild in Turkey. Journal of Food Engineering, 47, 333-336. http://dx.doi.org/10.1016/s0260-8774(00)00129-1

Demirci, B., Demirci, F., \& Baser, K.H. (2003). Composition of the essen-tial oil of Cotinuscoggygria(Scop.) from Turkey. Flavor and Fragrance Journal, 18, 43 44. http://dx.doi.org/10.1002/ffj.1149.

Denev, P., Petkova, N., Ivanov, I., Sirakov, B., Vrancheva, R., \& Pavlov, A. (2014). Determination of biologically active substances in taproot of common chicory (Cichoriumintybus L.), ScientificBulletin. Series F. Biotechnologies, 124 129

Dutra, R.C., Leite , M.N., \& Barbosa N.R. (2008). Quantification of phenolic constituents and antioxidant activity of Pterodon emarginatus Vogel seeds International Journal of Molecular Sciences, 9, 606-614. http://dx.doi.org/10.3390/ijms9040606

Genova, E., Hristova, J. and Beeva J. 1998, Pharmacia, 45, 10.

Habtemariam, S., \&Varghese, G.K. (2014). The antidiabetic therapeutic potential of dietary polyphenols. Current Pharmaceutical Biotechnology, 15, 391-400. http://dx.doi.org/10.2174/1389201015666140617104643.

Habtemariam, S., \& Lenti, G. (2015). The therapeutic potential of rutin for diabetes: An update. Mini Review. Medical Chemistry, 15, 524-528 http://dx.doi.org/10.2174/138955751507150424103721

Habtemariam, S., \& Varghese, G. K. (2015). Extractability of Rutin in Herbal Tea Preparations of Moringa stenopetala Leaves. Beverages, 1, 169-182. http://dx.doi.org/10.3390/beverages1030169.

Harbone ,J.B .(1993). In: The flavonoids. Advances in Research since 1986 Chapmann and Hall, London, 121-129.

Heim, K. E., Tagliaferro, A. R., \&Bobilya, D. J. (2002). Flavonoid antioxidants: chemistry, metabolism and structure-activity relation-ships. The Journal of 
Nutritional Biochemistry, 13, 572-584 . http://dx.doi.org/10.1016/s09552863(02)00208-5

Ilaiyaraja, N., \& Khanum, F. (2010). Evaluation of Antioxidant and Toxicological properties of Chicoryleaves. International Journal of Pharmacology and biological archives, 1(2), $155-163$

Ivancheva, S. \& Wollenweber E. (1989). Indian Drugs, 27, 167.

Ivancheva, S., Manolova, N., Serkedjieva, J., Dimov, V., \& Ivanovska, N. (1992). Plant Polyphenols, W. Hemingway and Laks, P. (Eds.), Premium Press, New York and London, 717. http://dx.doi.org/10.1007/978-1-4615-3476-1_43

Ivancheva S., \& Stancheva, B. (2000). Ethnobotanical inventory of medicinal plants in Bulgaria .Journal of Ethnopharmacology, 69, 165. http://dx.doi.org/10.1016/s0378-8741(99)00129-4 .

Ivancheva, S., Nikolova, M., \& Tsvetkova, R. (2006). Pharmacological activities andbiologically active compounds of Bulgarian medicinal plants, pp. 87-103, book Phytochemistry: Advances in Research, Editor: Filippo Imperato, Research Signpost, Kerala, IndiaKishore Dubey, N., Kedia, A., Prakash, B., \& Kishore, N (2015). Plants of Indian Traditional Medicine with Antioxidant Activity, pp. 114, book Plants as a Source of Natural Antioxidants, Edited by Nawal Kishore Dubey, Banaras Hindu University, India. http://dx.doi.org/10.1079/9781780642666.0001

Ivanova, D., Pavlov, D., Eftimov, M., Kalchev , K., Nashar, M., Tzaneva, M., \& Valchev S. (2013). Subchronic Toxicity Study of Ethanol Infusion from CotinusCoggygria Wood in Rats. Bulgarian Journal of Agricultural Science, 19 (2), 182-185.http://dx.doi.org/10.1016/j.jep.2004.08.033.

IvanovI., V, Rancheva, R., Marchev, A., Petkova, N., Aneva, I., Denev, P. Georgiev, G., \& Pavlov A.(2014). Antioxidantactivities and phenoliccompounds in Bulgarian Fumariaspecies. International Journal of Current Microbiology and Applied Science, 3(2), 296-306.

Jung,G., Shaffer, J., Varga., \& Everhart G. (1996). Performance of 'Grasslands Puna' Chicory at Different Management Levels Journal of Agronomy,88, 104 111. http://dx.doi.org/10.2134/agronj1996.00021962008800010022x

Kumar Ashok, P., \& Upadhyaya, K. (2012).Tannins are Astringent. Journal of Pharmacognosy and Phytochemistry, 1(3), 45-50.

Laguerre, M., Lecomte, J.\& Villeneuve, P. (2007) Evaluation of the ability of antioxidants to counteract lipid oxidation: existing methods, new trends and challenges. Progress in Lipid Research, 46, 244-282. http://dx.doi.org/10.1016/j.plipres.2007.05.002

Landzhev Chemical, I. (2010). Encyclopedia of Medicinal Plants in Bulgaria. Trud,Sofia, 551 (Bg).

Lin, L.U., Shu-wen, L., Shi-bo, J., \& Shu-guang ,W. (2004).Tannin inhibits HIV-1 entry by targeting gp 41. Acta Pharmacologica Sinica, 25(2):213-218. http://dx.doi.org/10.1038/aps.2009.31

Matic, S., Stanic, S., Bogojevic, D., Solujic, S., Grdovi, N., Vidakovic ,M., \& Mihailovic M.(2011). Genotoxic potential of CotinuscoggygriaScop. (Anacardiaceae) stem extract in vivo. Genetics and Molecular Biology, 34(2), 298-303.http://dx.doi.org/10.1590/s1415-47572011005000001.

Mihaylova, D., Georgieva, L., \& Pavlov, A. (2013). Invitroantioxidantactivity and phenoliccomposition of NepetacatariaL Extracts. International Journal of Agriculture Science and Technology, 1(4), 74-79.

Mihaylova, D., Georgieva, L., Pavlov, A. (2015). Antioxidantactivity and bioactive compounds of Rosa canina L.herbal preparations. Scientific Bulletin. Series F.Biotechnologies, 160-165.

Molan, A.L., Duncan, A.J., Barryand, T.N., \& McNabb, W.C. (2003). Effects of condensed tannins and crude sesquiterpene lactones extracted from chicory on the motility of larvae of deer lungworm and gastrointestinal nematodes. Parasitology International, 52, 209-218. http://dx.doi.org/10.1016/s13835769(03)00011-4

Muthusamy, V.S., Anand, S., Sangeetha, K.N., Sujatha, S., Arun, B., \& Lakshami, B.S. (2008). Tannins present in Cichoriumintybusenhanceglucoseuptake and inhibitadipogenesis in 3T3L1adipocytesthrough PTP1B inhibition. Chemico-Biological Interactions, 174 (1), 69-78. http://dx.doi.org/10.1016/j.cbi.2008.04.016

Nádia, R., Barbosa, R., Farah Silva, A., \& Caetano Polonini, H. (2015). Antioxidant Plants from Brazil. 97-108, book Plants as a Source of Natural Antioxidants, Edited by Nawal Kishore Dubey, Banaras Hindu University, India2015. http://dx.doi.org/10.1079/9781780642666.0097.

Nandagopal, S., \& Ranjithakumari, B.D. (2007). Phytochemical andantibacterialstudies of chicory (Cichoriumintybus L.) - a multipurposemedicinalplant. Advance in biological research, 1(1-2), 17-21.

Neoretal .(2006). Monography. Available from: http://neopharm.ro/data/ufiles/files/Neorenal-Monography.pdf

Novakovic, M., Vučkovic, I., Janackovic, P., Sokovic, M., Tesevic, V., \& Milosavljevic, S. (2007). composition, antibac-terial and antifungal activity of the essential oils of Cotinuscoggygriafrom Serbia. Journal of Serbian Chemical Society, 72, 1045-1051. http://dx.doi.org/10.2298/jsc0711045n.

Petkova, N., Vrancheva, R., Ivanov, I., Denev, P. , Pavlov, A., \& Aleksieva J.(2012). Analysis of biologicallyactivesubstances in tubers of Jerusalemartichoke(Helianthustuberosus $\quad$ L.). 50 years FoodRDIInternational Scientific-PracticalConference" Food,Technologies\& Health" Proceedings Book.
Rayne, S. \& Mazza, G. (2007). Biological activities of extracts from Sumac (Rhus spp.). Plant Foods for Human Nutrition, 62,165-175. http://dx.doi.org/10.1007/s11130-007-0058-4

Sando, C.E., \& Lloyd, J.R. (1924). The isolation and identification of rutin from the flowers of elder (Sambucus canadebsis L.). Journal of Biological Chemistry, $58,737-745$.

Stéphane, Q., Tatiana, V., Diana, K., Michael, J., Patrick, P., \& Christian, B. (2004). Main structural and stereochemical aspects of the antiherpetic activity of nonahydroxyterphenoyl containing Cglycosidic ellagitannins. Chemistry \& biodiversity, 1(2):247-58.http://dx.doi.org/10.1002/cbdv.200490021.

Taneva, I., Petkova, N., Dimov, I., Ivanov, I., \& Denev P. (2015). Characterization of Rose Hip (Rosa caninaL.) FruitsExtracts and Evaluation of Their in vitro AntioxidantActivity, Journal of Pharmacognosy and Phytochemistry, 5(2): 35-38

Vrancheva, R., Petkova, N., Ivanov, I., Denev, P., Pavlov, A., \& Aleksieva, J. (2012). Carbohydratecomposition andantioxidantactivity of rootextracts of InulaHelenium L.Youth Scientific conference "Klimentovidni", 3,62.

Winston, J.C. (1999). Health-promoting properties of common herbs. American Journal of Clinical Nutrition, 70, 491-499.

Yilmaz, Y., \& Toledo, R. T. (2004). Major flavonoids in grape seeds and skins: antioxidant capacity of catechin, epicatechin, and gallic Acid. Journal of Agricultural and Food Chemistry, 52, 255-260. http://dx.doi.org/10.1021/jf030117h

ZahidKhorshid, A., , Shalini, S., Sakeran, I.,ZidanNahla, M., Hasibur, R., \& Ansari A. A. (2015). Phytochemical, antioxidant and mineral composition of hydroalcoholic extract of chicory (Cichorium intybus L.) leaves . Saudi Journal of Biological Science,22, 322-326. http://dx.doi.org/10.1016/j.sjbs.2014.11.015. 